Article

\title{
Flood Management in California
}

\section{Jay R. Lund}

Department of Civil and Environmental Engineering, University of California, Davis, CA 95616, USA; E-Mail: jrlund@ucdavis.edu; Tel.: +1-530-752-5671; Fax: +1-530-752-7872

Received: 13 December 2011; in revised form: 29 January 2012 / Accepted: 3 February 2012 / Published: 14 February 2012

\begin{abstract}
California's development and success have been shaped by its ability to manage floods. This management has varied over the history of California's economic and political development and continues in various forms today. California will always have flood problems. A range of options are available to aid in flood management problems and have been used over time. These options can be contrasted with flood management elsewhere and the types of options used to manage other types of hazards in California, such as earthquakes, wildfires, and droughts. In the future, flood management in California will require greater reliance on local funding and leadership, reflecting diminished federal and state funding, with more effective state and federal guidance. Effective flood management will also tend to integrate flood management with actions to achieve environmental and other water supply objectives, both to gain revenues from a broader range of beneficiaries as well as to make more efficient use of land and water in a state where both are often scarce.
\end{abstract}

Keywords: California; flood; floodplain; management

\section{Introduction}

California is a land of many extremes. One extreme is floods. From its earliest days of statehood, California has had to contend with and eventually manage frequent and extreme floods. Flood management did not come easily to California, and remains a major issue for some areas of the state. This paper reviews the array of options available for flood management, the nature of floods in California, the history and current condition of flood management in California, as well as long term problems and solutions. Flood management is contrasted with flood management elsewhere and with 
the management of other hazards in California. Finally, some ideas for improving management and conclusions are presented.

\section{Flood Management Options}

A wide range of options can be discussed for flood management, and classified in various ways. Here, these options are classified by when they can be applied, in preparation for a flood, during a flood, and in flood recovery (Table 1). Options also are classified as actions which protect land uses from flooding ("Protection" actions) or reduce the vulnerability of land to flooding ("Vulnerability reduction," reducing damage and loss of life consequences when a flood occurs). An effective and cost-effective flood management program usually will combine these options suitably for local conditions. The history and future of flood management in California is the story of how these options have been employed and combined over time.

Table 1. Major flood management portfolio options.

\begin{tabular}{|c|c|}
\hline \multicolumn{2}{|c|}{ Preparatory actions } \\
\hline Protection & $\begin{array}{l}\text { Vulnerability reduction } \\
\text { (reduced damage and casualty potential) }\end{array}$ \\
\hline Levees & Relocation of vulnerable human activities \\
\hline Flood walls and doors & Floodplain zoning and building codes \\
\hline Closed conduits & $\begin{array}{l}\text { Floodproofing-raising structures, sacrificial first floor, } \\
\text { watertight doors, and flood vents }\end{array}$ \\
\hline Channel improvements and flood corridors & Flood warning and evacuation systems \\
\hline Reservoirs & Flood insurance and reinsurance \\
\hline Bypasses & Flood risk disclosure \\
\hline Sacrificial flooding & Public and policymaker education \\
\hline $\begin{array}{l}\text { Flood easements (bypasses and designated } \\
\text { flood areas) }\end{array}$ & Flood preparation and training exercises \\
\hline Local detention basins, drainage, and pumps & Floodplain mapping, gaging, data collection and availability \\
\hline Regular inspections, assessments, and maintenance & Community engagement and multi-hazard planning \\
\hline \multicolumn{2}{|c|}{ Response actions } \\
\hline Protection & Vulnerability reduction \\
\hline $\begin{array}{l}\text { Levee and flood wall monitoring (structures } \\
\text { and seepage) }\end{array}$ & Warnings, evacuation calls, and emergency mobilization \\
\hline $\begin{array}{l}\text { Flood fighting-sandbagging, sheet pile installation, } \\
\text { wave wash protection, splash cap installation, ring } \\
\text { levee construction, relief cut, pumping, and breach } \\
\text { closure and capping }\end{array}$ & High water staking \\
\hline Flood door closure and gate operation & \\
\hline $\begin{array}{l}\text { Reservoir operation-including coordinated } \\
\text { operations, rule curve operations and } \\
\text { encroachment, flash board installation, and } \\
\text { spillway surcharging }\end{array}$ & \\
\hline
\end{tabular}


Table 1. Cont.

\begin{tabular}{ll}
\hline \multicolumn{2}{c}{ Recovery actions } \\
\hline Protection & Vulnerability reduction \\
\hline Reconstruction and repair of flood infrastructure & Flood damage assessment-flood infrastructure surveys, \\
& system performance, damage, response costs \\
& Flood insurance and reinsurance \\
& Reconstruction and repair \\
& Relocation or reconstruction to reduce future flood \\
& vulnerability \\
\hline
\end{tabular}

\section{Floods in California}

The frequency, magnitude, and duration of floods are driven by local climate and basin characteristics. California is a large and diverse state with somewhat different flood regimes in different regions. In each area, floods have been managed somewhat differently. Also, the hydrologic variability of floods in each area served somewhat different ecological functions before the economic development of California's lands and rivers [1]. Most flood problems in California tend to have different characters, depending on local regions, as summarized in Table 2.

Table 2. Major flood types in California.

\begin{tabular}{l}
\hline Lands below sea level \\
Sacramento-San Joaquin Delta: Large areas of deeply subsided diked lands, mostly agricultural, but with \\
important statewide water supply and ecosystem implications; immediate flood causes can range from \\
high river flows, earthquakes, burrowing animals, and ship grounding, exacerbated by long term land \\
subsidence and sea level rise. Managed mostly by local levee maintenance districts with significant \\
dependence on state funding. \\
Major River Flooding \\
\hline Sacramento Valley, San Joaquin Valley, major north coast rivers: Flooding from major rainstorms \\
(particularly "atmospheric rivers") or snowmelt. Floods can cover large areas to substantial depths and \\
cause large amounts of property damage and life loss. Flood protection mostly by levees, bypasses, and \\
upstream reservoirs. Flood warning and evacuation systems are usually effective in reducing loss of life, \\
except where levee breaches cause rapid deep flooding. Largest potential damage for Sacramento \\
metropolitan area, Marysville/Yuba City area, Stockton, and about 27 smaller river towns. Managed by \\
regional water and flood control projects involving local, state, and federal governments. \\
\hline Rapid River flooding \\
\hline Most common in Southern California and alluvial fans: Local floods caused by intense rainstorms on \\
steep watersheds, which can also include substantial debris flows. Property damage can be large over a \\
small area, and loss-of-life risks are larger due to difficulties with flood warning. Managed by local \\
governments (particularly using land use authority) with involvement from federal and state governments. \\
\hline Local rainfall flooding \\
\hline Everywhere: Flooding of small areas to shallow depths caused by local rainfall or rapid snowmelt. \\
Inconvenience can be frequent, but property damage is usually small and loss of life is relatively rare. \\
Managed mostly by landowners and local governments. \\
\hline
\end{tabular}


Table 2. Cont.

\begin{tabular}{l}
\hline Dam failures \\
Dam failures are infrequent in California, but there is always some residual risk, particularly given the \\
large earthquakes which can occur in California. Roughly 1,250 sizable non-federal dams are regulated by \\
the California Department of Water Resources Division of Dam Safety. \\
\hline Coastal flooding \\
Coastal storms and tsunamis are a risk in low-lying coastal areas. These risks will increase with sea level \\
rise and continued coastal development. Managed mostly by coastal hardening and warning and \\
evacuation systems.
\end{tabular}

For all of California, most flood-generating storms arrive in the winter with predominantly orographic precipitation. Particularly in northern and central California, snowfall and snowmelt are important. Colder storms tend to have more precipitation fall as snow, and cause less flooding than comparable precipitation from rainier warmer storms. However, the accumulation of snowpack from earlier cold storms can contribute greater runoff from following warmer storms [2].

At the end of the winter and into the spring (particularly March and April, but sometimes into July), snowmelt floods can arise in northern California. Flow peaks for snowmelt floods tend to be less than the larger rain-generated floods, but have much larger volumes and durations of high flows.

Most significant floods in California are caused by "atmospheric rivers" from the Pacific Ocean, which include warmer and more intense "pineapple express" storms, in California parlance, where a stream of warm atmospheric moisture precipitates for several concentrated days over the mountains of California. [3-5] (Figure 1) Historically, large examples of these storms flooded much of the Sacramento Valley, with floods as large as $17,000 \mathrm{cms}(600,000 \mathrm{cfs})$ near Sacramento. The size and flatness of the Sacramento and San Joaquin Valleys, with high tributary mountain watersheds, can bring large amounts of water quickly to slow-draining populated and agricultural areas, making them especially flood-prone.

Figure 1. "Atmospheric Rivers" bring major floods to California, 31 December 1996, 1800 UTC, GOES-9 image [6].

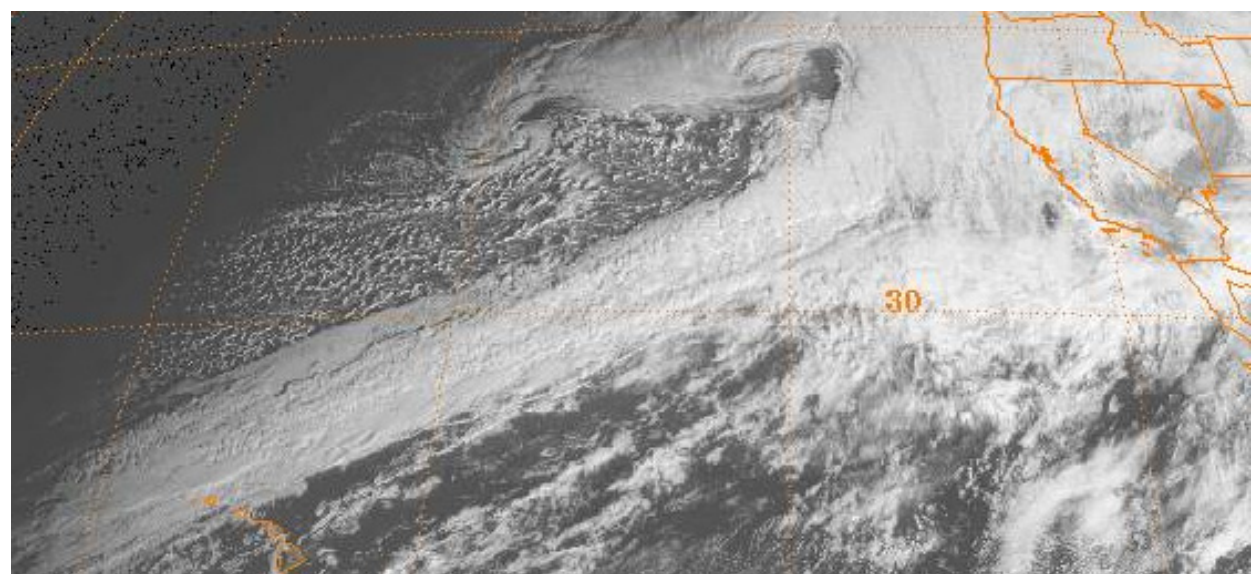

North Coast rivers, having less snowpack and more direct access to Pacific Ocean moisture, are similarly exposed to major floods. However, their smaller drainage areas and low population densities make damages there, while locally significant, less important from a statewide perspective. 
In southern California, steeper and smaller watersheds close to urban settlements cause floods to develop rapidly for shorter periods of time. Debris flows and mud slides accompany floods in some steeper areas. Warnings and evacuations are more difficult. Damage reduction is more reliant on land use planning and large channel capacities, along with some detention storage, particularly for debris flows [7].

A unique form of flooding occurs in the subsided islands of the Sacramento-San Joaquin Delta, which often lie several meters below sea level and are protected by relatively weak levees. Although many floods are caused by high water from storm-generated inflows, island failures also can arise from higher than usual tides, animal burrowing, earthquakes, ship grounding, and other causes. Continued land subsidence and sea level rise will worsen flooding problems in this area $[8,9]$.

Dam failures are rare in California, but still pose potentially significant residual risks, especially given the state's susceptibility to major earthquakes. (Residual risk is the risk remaining after flood management activities have been undertaken.) The largest dam failure in California was the St. Francis dam collapse in 1928, killing hundreds of people. Smaller failures or partial failures have occurred at Lower San Fernando Dam (1971, earthquake), Calaveras Dam (1918, in construction), San Luis Dam (1981, drawdown), and elsewhere, requiring repairs or reductions in capacity. Potential inundation areas for major dam failures in the densely populated San Francisco Bay Area are illustrated in Figure 2.

Figure 2. Dam failure inundation areas for the San Francisco Bay Area [10].

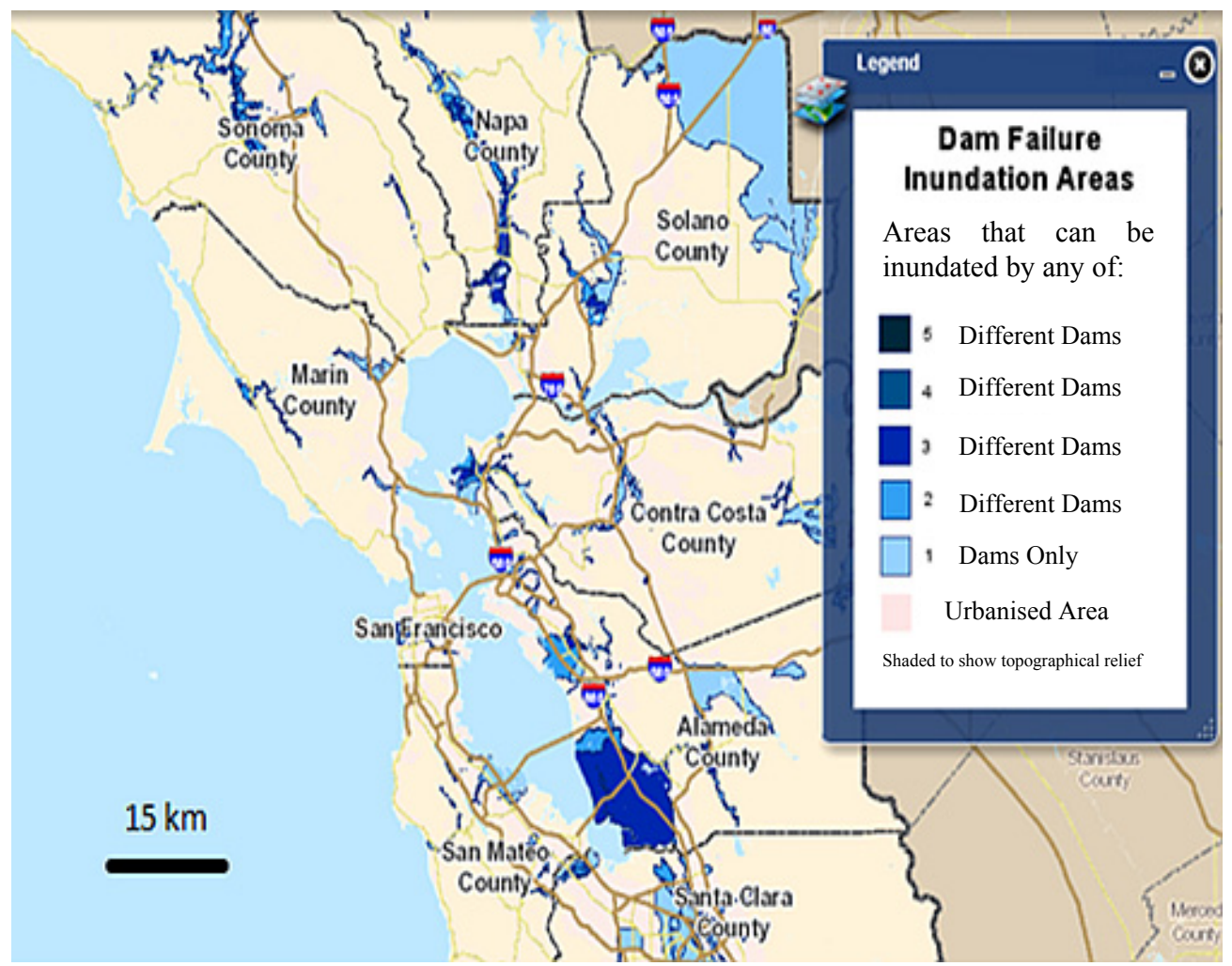

Coastal flooding occasionally occurs from storms and tsunamis. Tsunami and coastal flood warning systems are in place. However, coastal flooding is expected to increase with sea level rise and continued development in coastal areas, posing both economic and environmental difficulties. 


\section{Managing Floods in California}

Early European settlers to California faced abrupt climate change, relative to the more humid non-Mediterranean climate they came from on the eastern seaboard of the United States. Instead of a climate with predominantly summer precipitation and major hurricane-driven floods, they came to an overwhelmingly winter precipitation climate with major winter floods from winter "atmospheric river" events. As the settlers came to understand the flood-prone nature of California's semi-arid climate, they were driven to create local institutions for flood management [11]. California's ever-changing economy and society have also changed the nature and importance of California's flood problems with time.

Floods are always most acutely felt locally. Flood management in California began with unaided flood protection efforts by local landowners. Local flood efforts were then aided by legislation enabling formation and governance of local levee or reclamation districts in 1868, allowing groups of landowners to more efficiently build more effective levees for a district, rather than a single property. These efforts reduced seasonal flooding in most years. However, as the number of districts grew, often on opposite sides of the river, violent interactions sometimes arose among neighboring levee districts during floods. Larger floods would often overwhelm many levee districts.

Following major floods in 1907, it was widely recognized that the system of local levees had created a regional fragility to large storms, with potential to stymie urban and agricultural development in the Sacramento Valley. State and federal authorities, after years of study, developed a set of flood bypasses, channel expansions, and stronger project levees to provide greater relief from large floods and more systematic coordination of levees and channels. The bypass system was built largely during the 1920s under federal and state authority, with local levee districts remaining in charge of levee maintenance. The bypass system restored some of the flood channel capacity, eliminated by earlier levee construction, by building large seasonal channels with flood easements purchased from farmers (who conduct seasonal farming in the bypasses). These bypass channels are separated from the main stem of the Sacramento River by low weirs which overtop with high water (Figure 3).

A major problem for flood management in the Sacramento Valley during the early 1900s was the immense quantity of debris and sediment from earlier gold mining in and near the rivers. To mobilize these sediments, which had greatly raised local river beds, levees were placed close to the river to induce scour. While this placement of levees was effective in mobilizing sediment, now that most accessible mining sediment has flushed from the system, the close placement of river levees has caused problems of levee erosion and increased the cost of making improvements to levees as higher levels of protection are desired for more valuable and populated land uses in protected floodplains.

With the development of major water supply storage reservoirs, starting in the 1940s through the early 1980s, reservoir flood storage was added to the flood management system. Almost all major reservoirs have a reserved seasonal flood management pool to reduce peak flows from storms. This flood capacity was paid for and regulated by the federal government.

Because California's flood season falls outside of the major water use and irrigation season, reservoir operations are better able to both moderate floods and supply water, compared to reservoirs in climates with wet summers, such as China or the Eastern U.S. With climate warming, the loss of snowpack will force reservoirs to operate more for floods, which will be more rain-fed and less snow-melt. 
Although a warmer climate will be inconvenient and cause modest costs, if well managed, climate change alone seems unlikely to cause catastrophe [2,12]. Shifting drought water storage from surface reservoirs to aquifers can also make substantially more storage capacity available for winter flood management [13]. This shift will require integrated reoperation of many flood and water supply system elements.

Figure 3. Sacramento River Bypass system [14].

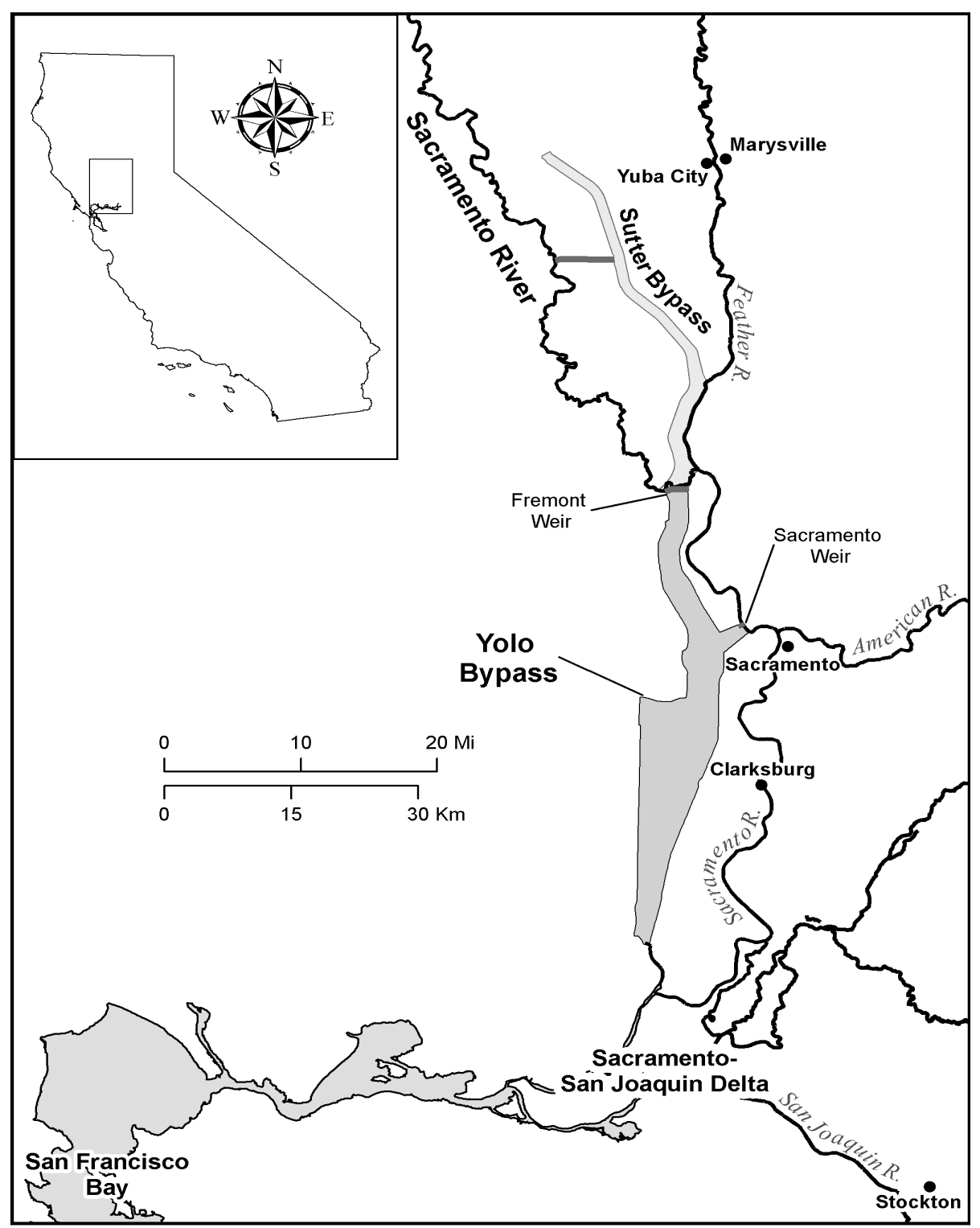

\section{Current Flood Problems and Risks}

As summarized in Table 2, small frequent floods are fairly well managed in California, in terms of economic risk. Residual risks are large in some places, but California's flood problems are more of a collection of local flood problems, sometimes with regional management implications, than a core threat to California's society and economy, as they arguably were a century ago [14-19].

Despite the tremendous successes of flood management in California, California will always remain prone to major floods and flooding. The extremes of California's climate are unlikely to moderate. 
Economically, it is infeasible and undesirable to prevent all floods, as the cost of preventing floods from all storms and extreme conditions comes to exceed the damages incurred, particularly in an expected value and risk-based sense. Also, as a levee-dominated flood management system, much of the Central Valley will always retain a substantial residual risk of levee breaches and the major damages and potential loss of life that such sudden and deep floods entail.

Flood potential remains significant and even limiting for several major urban areas of California, as well as more numerous small towns. The Sacramento metropolitan area, including the cities of Sacramento and West Sacramento, remains one of the most flood-prone urban areas of the country. The Marysville-Yuba City and lower reaches of the Feather River are also inherently flood-prone. Parts of Stockton, Napa, Victorville, and areas of Santa Clara and Ventura counties also are flood-prone, often with unique circumstances. Some urban areas of southern California also have potential for major urban flooding [18,19]. Smaller former river towns, such as Clarksburg, as well as some small Delta towns on subsided or low-lying lands (such as Bethel Island) are more difficult flood-prone areas, with little economic activity to support flood protection actions. Recent legal rulings (the "Paterno decision") which found the state government of California liable for damages from flooding in areas protected by state project levees have shifted flood responsibilities toward state government, and have led to increased state activity in flood management.

Greater potential and opportunities remain for the management of more frequent floods for environmental purposes [20,21]. Frequent seasonal floodplain inundation was historically important for many of California's native fish species as well as migratory waterfowl. Today, roughly $95 \%$ of native wetlands in the state have been leveed and drained, mostly for agriculture as well as for urban uses and salt production in some areas. Re-connecting floodplains to rivers to allow for seasonal flooding is a major environmental objective which will take decades to realize. Over such a long period of time, there will be opportunities to re-configure and expand parts of the levee system by setting them back from the river or improving the system of bypasses [14,22]. Such changes in the levee and bypass system provide opportunities to improve environmental performance, as well as to increase flood channel capacities and reduce scour of levees, reducing economic risk from floods. Alas, most environmental benefits will come from small frequent floods, whereas most flood protection benefits will come from avoiding very large infrequent floods. Environmental and flood benefits will also often require more complex planning due to likely greater losses of water stored for agricultural and urban water supplies during the summer.

The management of floods in California is going through major transitions. With the decline in federal budgets and capabilities, leadership has shifted back to local and state governments. Local leadership has been particularly effective. Following the 1986 flood, which nearly overwhelmed levees for Sacramento, the flood protection level for the city was downgraded from one in 500 years to about once in 60 years (annual exceedence probability from 0.002 to 0.017 , or $0.2 \%$ to $1.7 \%$ ) [22]. In 1989, several local governments in the Sacramento area, east of the river, formed SAFCA (Sacramento Area Flood Control Agency) to better coordinate local, state, and federal actions for flood protection in the member area. SAFCA has been very effective in marshalling federal, state, and local resources to improve levee reliability, expand flood channel capacity, improve the outlet capacity for Folsom Dam, and reduce development potential in rural areas on the western side of the Sacramento River. 
Following decades of local, state, and federal neglect, attention brought by the 2005 Katrina flood of New Orleans, California voters approved two general obligation bonds in 2006 with $\$ 5$ billion to support flood management. California also passed legislation requiring urban areas of the Central Valley to eventually adopt 200-year levels of flood protection for major river floods $(0.5 \%$ annual exceedence probability). This has rejuvenated state flood management efforts and investments, particularly levee improvements, although roughly $\$ 20$ billion more is estimated to be needed for flood system improvements. After the flood bonds are all expended, flood problems and risks will remain, and it will be important for the state to establish a sustainable finance model for local and state support of flood operation, maintenance, and assessment. State government has largely supplanted federal leadership in flood policy in California [22].

\section{Contrasts}

Flood management in California can be compared with other parts of the world. Flood management in the Sacramento Valley has significant parallels with management of the Mississippi River, which was another major national flood hazard area in the first half of the 1900s. On both systems, the U.S. Army Corps of Engineers was active in designing major basinwide flood management systems, particularly the combined use of flood bypasses and levees [11]. Bypasses have been very successful for both systems, however the shorter duration of floods in California give reservoirs a greater role in reducing peak flows. In the Netherlands, where major river floods also tend to have long durations, upstream reservoirs, largely outside of Dutch territory, are not of major importance, and dikes, levees, and bypasses are important [23]. In China, historical floods arguably shaped early Chinese civilization, but are now largely managed, in most years, with a system of levees, reservoirs, and retention areas. In all these regions, floods have historically shaped the region's land use, economy, and society. While floods have been largely "tamed" for these regions, substantial residual risk remains, along with challenges for managing floods for ever-changing economic and societal objectives. In these cases, major expenses for construction of flood management infrastructure has been supported by national governments, reflecting the national importance of flood control at the times when these projects were constructed. Operations and maintenance is largely left to local and state agencies. Flood damages are almost non-existent in the Netherlands, due to their much higher economically-designed risk safety standards (up to one in 10,000 years for urban areas) [23]. Flood damages on the Mississippi River system are largely paid by land users through flood insurance and uncompensated damages. The U.S. East Coast is subject to major hurricane flooding from rains and storm surges over very large areas. Dunes and occasional urban storm barriers provide some protection, but most flood risk reduction is from reducing the vulnerability of coastal communities to flooding by land use actions, building codes (particularly elevated structures), and strong flood warning and evacuation systems.

California's management of floods also can be compared with the management of other hazards in California, such as earthquakes, fires, and droughts. Major earthquake hazards, which vary throughout the state, are managed primarily by using building and construction codes and earthquake design to make structures resistant to all but the largest earthquakes. Some structures carry earthquake insurance. So most earthquake-related costs are therefore borne by building owners, both in construction costs and insurance, as well as damage (although considerable federal and state relief and recovery support 
also becomes available). Wildfires are another major hazard in California. Wildfires occur in most years and can damage large exurban and even suburban areas, such as the Oakland Hill fire of 1991 (\$3.5 billion in damage). Most damage is covered by homeowners' insurance, and rural homeowners often pay fees to support fire protection services. Effective local evacuation programs have eliminated most wildfire-related deaths (fire damages commonly exceed $\$ 1$ billion/year) [24]. Droughts in California are mostly managed by water agencies and utilities. Seasonal droughts have been largely eliminated through the use of surface reservoir and aquifer water storage, mostly by local agencies and water users as well as through major reservoir projects. Today, major drought losses occur from large over-year droughts, and many are concerned with additional perhaps permanent losses with climate change [13]. Disaster relief aid is minimal for droughts in California, with most expenses for accommodating and managing for droughts being borne by water users themselves. Given the low frequency of major flooding in California, it is important that floodplain emergency management be brought into other local and state emergency management activities, such as for fires, drought, and earthquakes (which rarely occur at the same time or season). Federal disaster response efforts are largely centralized with the U.S. Army Corps of Engineers and Federal Emergency Management Agency (FEMA).

\section{Some Ideas for the Future}

For California, the future of flood management seems likely to be as tied to restoring ecosystem functions as to traditional economic risk and public safety. Managing economic risks and public safety will take the form mostly of major investments in stronger levees to protect urban areas. However, there are also large opportunities to simultaneously reduce economic risks (especially for large floods) and improve environmental performance by re-connecting some floodplain lands and bypass systems with rivers to allow more seasonal flooding. This reconnection and recreation of seasonal floodplain wetlands has substantial environmental potential for native fish and waterfowl, and if done carefully, can also improve bypass and river channel capacities while reducing scour on mainstem river levees. Similarly, there will be interactions between flood and water supply functions of California's water management system [22].

Climate change, particularly climate warming, will be an issue for flood operation of reservoirs. Greater winter peaks and volumes are likely, with reductions in later snowmelt. Many reservoirs seem capable of regulating such floods, sometimes with modifications to operating rules, although longer periods of high flows may increase levee scour [2,12]. The combination of continued urban growth and climate change are likely to make larger and perhaps set-back levees more desirable $[25,26]$. Discussion of climate change raises another point for flood management more generally, that we are likely to never have a great deal of certainty regarding the frequency distribution of flood peaks, durations, and volumes [27,28]. Nevertheless, probabilistic risk analysis remains the most rational framework for understanding and evaluating flood problems and solutions [22].

Flood management in California, and elsewhere, is always hampered by a lack of stable financial resources. Federal, state, and local resources are often committed in the immediate aftermath of floods, especially for recovery, but operation, maintenance, and planning are often neglected for decades without major floods. Federal and state budget problems are likely to worsen funding problems for 
flood management. Without sustained funding for flood management, land use management is often driven by private and local revenue potential from new floodplain development and water management is driven by demands for water supply, both of which can work to increase flood risks.

Many ideas can be explored for better managing floods in California [16,29]. Some of these include:

- More portfolio-based approaches to flood management, with greater coordination in the planning and operation of preparatory, response, and recovery actions to increase protection and reduce vulnerability (Table 1) [22].

- Establish floodplain land use and insurance policies which come into effect only after some years, or a decade, to make the transition to new policies easier in political and economic terms.

- Impose a state-collected fee on land uses in the flood plain to cover flood damages, essentially insuring the state for its liability for flood damages in areas covered by state flood control projects. Such a fee might also take the form of a flood damage bond on new development (insuring the additional risk from new urban development in floodplains).

- Better coordinate local, state, and federal actions to take advantage of the comparative advantages of each level of action and institution [22].

Flood management in California's Central Valley is currently being examined under the ongoing State of California FloodSAFE effort [14]. In the coming months and years, there will be improvements in our abilities to characterize and model floods, flood damages, and flood management and policies. If accompanied by political leadership, such technological advances should greatly improve flood safety and reduce the ecological impacts of flood management.

\section{Conclusions}

California has had considerable success in managing floods. Large, mostly agricultural, parts of California are now roughly suitably protected from floods, in a risk analysis sense. However, several large urban areas remain at large risk of flooding, including the state capital, and there is considerable urban development pressure in many deep floodplains behind fairly weak levees. Much of the state's water supply would also be at risk from flooding of subsided lowlands in the Sacramento-San Joaquin Delta. So, despite significant successes, a large and growing residual flood risk remains. Fortunately, the state and many local governments now understand these risks better and have embarked on a major effort to improve flood protection and management. Time will tell if these efforts are fruitful.

\section{Acknowledgments}

Nathan Burley and Christy Jones, two anonymous reviewers, and two editors are thanked for suggestions on earlier drafts. Anna Fryjoff-Hung is thanked for her cartography.

\section{References}

1. Moyle, P.B.; Bennett, W.A.; Fleenor, W.E.; Lund, J.R. Habitat variability and complexity in the upper San Francisco estuary. San Francisco Estuary Watershed Sci. 2010, 8, 1-24.

2. Willis, A.D.; Lund, J.R.; Townsley, E.S.; Faber, B. Climate change and flood operations in the Sacramento Basin, California. San Francisco Estuary Watershed Sci. 2011, 9, 1-18. 
3. Dettinger, M. Fifty-Two Years of "Pineapple-Express" Storms across the West Coast of North America; PIER Project Report; Prepared for California Energy Commission, Public Interest Energy Research Programme; December 2004; CEC-500-2005-004.

4. Dettinger, M.; Ralph, F.; Das, T.; Neiman, P.; Cayan, D. Atmospheric rivers, floods and the water resources of California. Water 2011, 3, 445-478.

5. Ralph, F.M.; Neiman, P.J.; Wick, G.A.; Gutman, S.I.; Dettinger, M.D.; Cayan, D.R.; White, A.B. Flooding on California's Russian River: Role of atmospheric rivers. Geophys. Res. Lett. 2006, 33, doi: 10.1029/2006GL026689.

6. GOES Data; National Climate Data Center: Asheville NC, USA, 2012. Available online: http://www.ncdc.noaa.gov (accessed on 11 February 2012).

7. Rantz, S.E. Urban Sprawl and Flooding in Southern California; USGS Circular 601-B, U.S. Geological Survey: Menlo Park, CA, USA, 1970.

8. Lund, J.; Hanak, E.; Fleenor, W.; Bennett, W.; Howitt, R.; Mount, J.; Moyle, P. Comparing Futures for the Sacramento-San Joaquin Delta; University of California Press: Berkeley, CA, USA, 2010.

9. Suddeth, R.; Mount, J.F.; Lund, J.R. Levee decisions and sustainability for the Sacramento San Joaquin Delta. San Francisco Estuary Watershed Sci. 2010, 8, 1-23.

10. Earthquake and Hazards Program. Dam Failure Inundation; Association of Bay Area Governments: St. Oakland CA, USA, 2011. Available online: http:/quake.abag.ca.gov/damfailure/ (accessed on 11 February 2012).

11. Kelley, R. Battling the Inland Sea; University of California Press: Berkeley, CA, USA, 1989.

12. Connel-Buck, C.R.; Medellín-Azuara, J.; Lund, J.R.; Madani, K. Adapting California's water system to warm vs. warm-dry climates. Clim. Change 2011, 109, 133-149.

13. Tanaka, S.K.; Zhu, T.; Lund, J.R.; Howitt, R.E.; Jenkins, M.W.; Pulido, M.A.; Tauber, M.; Ritzema, R.S.; Ferreira, I.C. Climate warming and water management adaptation for California. Clim. Change 2006, 76, 361-387.

14. California Department of Water Resources (DWR). 2012 Central Valley Flood Protection Plan; DWR: Sacramento, CA, USA, 2011. Available online: http:/www.water.ca.gov/floodsafe/ (accessed on 11 February 2012).

15. California Department of Water Resources (DWR). Responding to California's Flood Crisis; DWR: Sacramento, CA, USA, 2005. Available online: http://www.water.ca.gov/pubs/flood/ flood_warnings__responding_to_california\%27s_flood_crisis/011005floodwarnings.pdf (accessed on 11 February 2012).

16. U.S. Army Corps of Engineers (USACE). Post-Flood Assessment for 1983, 1986, 1995, and 1997 Central Valley, California; USACE, Sacramento District: Sacramento, CA, USA, 1999.

17. California Floodplain Management Task Force. California Floodplain Management Report: Recommendations of the California Floodplain Management Task Force (Galloway Report); California Department of Water Resources: Sacramento, CA, USA, 2002.

18. Alluvial Fan Task Force. Alluvial Fan Task Force: Findings and Recommendations Report; California Department of Water Resources: Sacramento, CA, USA, 2010.

19. Alluvial Fan Task Force. The Integrated Approach for Sustainable Development on Alluvial Fans; California Department of Water Resources: Sacramento, CA, USA, 2010. 
20. Jeffres, C.A.; Opperman, J.J.; Moyle, P.B. Ephemeral floodplain habitats provide best growth conditions for juvenile Chinook salmon in a California river. Environ. Biol. Fishes 2008, 83, 449-458.

21. Opperman, J.J.; Galloway, G.E.; Fargione, J.; Mount, J.F.; Richter, B.D.; Secchi, S. Sustainable floodplains through large-scale reconnection to rivers. Science 2009, 326, 1487-1488.

22. Hanak, E.; Lund, J.; Dinar, A.; Gray, B.; Howitt, R.; Mount, J.; Moyle, P.; Thompson, B. Managing California's Water: From Conflict to Reconciliation; Public Policy Institute of California: San Francisco, CA, USA, 2011; pp. 1-500.

23. Woodall, D.L.; Lund, J.R. Dutch flood policy innovations for California. J. Contemp. Water Res. Educ. 2009, 141, 45-59.

24. Ross, T.; Lott, N. A Climatology of 1980-2003 Extreme Weather and Climate Events; National Climatic Data Center Technical Report No. 2003-01; NOAA: Asheville, NC, USA, 2003.

25. Zhu, T.; Lund, J.R. Up or out?-Economic-engineering theory of flood levee height and setback. J. Water Resour. Plan. Manag. ASCE 2009, 135, doi:10.1061/(ASCE)0733-9496(2009)135:2(90).

26. Zhu, T.; Lund, J.R.; Jenkins, M.W.; Marques, G.F.; Ritzema, R.S. Climate change, urbanization, and optimal long-term floodplain protection. Water Resour. Res. 2007, 43, doi:10.1029/2004WR003516.

27. Klemes, V. Sensitivity of water resource systems to climatic variability. In Common Sense and Other Heresies: Selected Papers on Hydrology and Water Resources Engineering; Klemes, V., Ed.; Canadian Water Resources Association: Cambridge, ON, Canada, 2000.

28. Klemes, V. Design implications of climate change. In Common Sense and Other Heresies: Selected Papers on Hydrology and Water Resources Engineering; Klemes, V., Ed.; Canadian Water Resources Association: Cambridge, ON, Canada, $2000 \mathrm{~b}$.

29. Burby, R.J. Flood insurance and floodplain management: The U.S. experience. Environ. Hazards 2001, 3, 111-122.

(C) 2012 by the authors; licensee MDPI, Basel, Switzerland. This article is an open access article distributed under the terms and conditions of the Creative Commons Attribution license (http://creativecommons.org/licenses/by/3.0/). 